\title{
Ecological media perspective on WhatsApp status features
}

\author{
Rosa Apriliyanti \\ Supervisor Marketing Branding \\ PT. Utomodeck Metal Works, Surabaya \\ Address: Jalan Basuki Rahmat No. 149, Surabaya \\ E-mail: rosaapriliyanti34@gmail.com
}

\begin{abstract}
The presence of the internet today makes it easy for users to carry out communication activities without limitation of distance and time. Even instant messaging such as WhatsApp, which has the primary function as a medium for communication, can be a mediator for self-existence and cannot be separated from its users to share daily activities through the WhatsApp Status feature. The purpose of this study was to analyze the Status feature on Instant Messaging WhatsApp as a mediator to show self-existence without distance and time limits based on media ecology theory. The method in this study is a qualitative method with purposive data collection techniques. Researchers also conducted interviews with seven informants who were students and workers. This study's results indicate that the presence of this feature affects various actions, perceptions, and communication experiences in society. Ecological media has the perspective that electronic media has radically changed society. In essence, society is very dependent on technology that uses media, and that the social order of a society is based on its ability to deal with these technologies. Media, in general, act directly to form and organize culture. Apart from that, ecological media also has assumptions about how technology affects society, include the distinction between hot and cold media.
\end{abstract}

Keywords: instant messaging, WhatsApp, technology, media ecology, communication

\section{Introduction}

In the book Understanding Media, McLuhan wrote about the influence of technology such as wall clocks, television, radio, film, telephone, and even roads and games. McLuhan was interested in the social impact generated by the primary forms of communication using this medium. In other words, McLuhan wanted to see what the relationship is between technology and members of a culture (West \& Turner 2008).

The first to introduce media ecology was Neil Postman in 1968, summarizing the leading theory and methodology as looking 'into the problem of how the media to communicate influences human perception, understanding, feelings and values' (Hildrebrand 2018). Media ecology is associated with materiality ('structure') and mood and mobility ('impact'). 'In terms of the media environment (e.g., books, radio, film television, and others). The media create certain environments at different costs shaping movement, mood, and message depending on the device's materiality, among other elements. This smartphone is not only a 'machine' but also carries specific physical, virtual, mental, and emotional settings in a broad sense (Hildrebrand 2018).

McLuhan's research is very different from others in that it places communication at the center of attention. In McLuhan's scheme, there is nothing else on stage. Everything communication. In Understanding the Media, Levinson (2000), he considers at least as much technology as each translated and explored as a medium of communication. McLuhan Harold Innis as the second most important contributor to Media Ecology, after Neil Postman, understands and interprets not just telephones and television, which Innis is missing (partly because Innis does not focus on electronic media, partly because the TV has only just appeared on the scene when Innis was working.) However, 
money, clothes, cars, and weapons are also essential media in McLuhan's book. That whether we pay for something by cash, check, or credit card affects who the medium users are (Levinson 2000).

Media Ecology Theory has several assumptions that media's influence and technology on society is the main idea behind Media Ecology Theory. The three assumptions are as follows (West \& Turner 2008);

(1) The media encompass every action in society,

(2) The media refine our perceptions and organize our experiences,

(3) The media unites the whole world.

The first assumption underlines the idea that we cannot escape the media in our lives. Media pervades our entire being, so we cannot avoid or escape from it. Many media ecology theorists interpret media in broad terms. McLuhan stated that media has a broad interpretation because media is always present in our lives. These media transform society through the games we play, the radio we listen to, the television we watch (West \& Turner 2008).

The second assumption of media ecology theory relates that the media directly influence us. Media ecological theorists believe that the media improve the perceptions of organizing our lives. McLuhan stated that the media is quite strong in our view of the world (West \& Turner 2008). For example, what happens when we watch television, if television news reports that Indonesia is experiencing a moral decline in adolescents, then television will display news about theft, brawl, free sex, and others.

The third assumption of ecology has given rise to a reasonably famous line: Media connects the world. McLuhan uses the term global village to describe how the media binds the world into a massive political, economic, social, and cultural system. In particular, electronic media can bridge cultures that would never have communicated before this connection (West \& Turner 2008).

After understanding the three media ecology theory assumptions, McLuhan also introduced a famous line; namely, the medium is the message. This equation's exact meaning is to present McLuhan's scientific values: the content of messages using the media is secondary to the medium (or communication channel). The medium can change how we think about other people, ourselves, and the world around us (West \& Turner 2008).

An example of an electric lamp may prove to be lit in this connection. Electric light is pure information. It is a message less medium, as it were unless it is used to spell some verbal advertisement or name. This fact, characteristic of all media, means that any medium's "content" is always another medium. Written content is speech, just as the written word is printed content, and printed is telegraphic content. If asked, "What is the content of the conversation?" it is necessary to say, "This is an actual thought process, which in itself is non-balancing." An abstract painting is a direct manifestation of the creative thought process. Ice because they might appear in computer design. What we are considering here, however, are the psychic and social consequences of designs or patterns when they strengthen or speed up existing processes. The "message" of any medium or technology is the change in scale or speed or pattern incorporated into the human problem. Railways do not introduce movement or transport or wheels or roads into human society, but rather accelerate and scale up previous human functions, creating entirely new kinds of cities and new kinds of work and recreation. That is the case of whether rail is functioning in tropical or northern environments (McLuhan 1964).

In addition to the statement of the medium is the message, McLuhan (1964) also classified media as hot or cold media. Hot media (hot media) has a description as a medium that demands little from listeners, readers, or viewers. For example, film and radio, McLuhan acknowledge that radio can function as background sound, as a control level of interference, or for listening pleasure, and no involvement is required in using radio (West \& Turner 2008). 
Meanwhile, cool media requires a high level of participation, and this medium has low defines. Cold media requires the audience to create meaning through an imaginative and high involvement of the senses. Examples are cartoons, conversations, seminars, telephone, and TV (West \& Turner 2008).

Technological developments continue to evolve, along with human civilization. The ease of technology also affects the actions, perceptions, and culture of the social community in globalization. According to Robertson in Barker (2015), the concept of globalization refers to an intensive narrowing of the world and increasing awareness of the world, namely the increasing global connections and our understanding of them. Barker (2015) explains that globalization allows time, space, and (local) places to be separated from each other, allowing various social relations to develop between people who do not live side by side. Simultaneously, the development of new forms of communication and information control made it possible for transactions to be carried out at all people and times so that certain places were entered and shaped by social influences quite distant from them. An example is the development of the internet.

Today the internet is no longer taboo for the whole society. From children to adults, they can play internet skillfully. People can use the internet to get what they might not get in the real world. The sophistication of the internet is the main reason they use the internet to facilitate all their activities. Anyone can access the internet anywhere by utilizing facilities, such as cellphones, Ipad, laptops, or even Wi-Fi services. Such easy use is an advantage of the internet. According to data from the Kementerian Komunikasi dan Informatika or Ministry of Communication and Informatics (2017), in Indonesia alone, internet users have reached more than 48 million people. As social beings, "We cannot help but communicate," so communication is closely related to people's lives.

In 1995, a chat application called mIRC emerged. The application is a paid software for online conversations that run on the Windows operating system. After that application came E-mail, then came various websites, blogs, and other social networks, and after that came Instant Messaging. Instant Messaging is an application that can be used on cell phones, laptops, and tablets. The use of this technology makes communication activities between individuals more accessible, faster, and more efficient (Meisyaroh 2014). Instant messaging, such as WhatsApp, LINE, and BBM, strive to meet human needs more comfortable to communicate. Many Indonesians have benefited from the use of instant messaging. Instant messaging has now developed into a two-way communication platform that allows active user engagement (Chou et al. 2010 in Tjokro 2016).

Instant Messaging is a form of synchronous communication. Users send messages to their interlocutors and receive instant replies, thus engaging in almost real-time text-based exchanges (Baron in Mesch, Talmud, \& Haase 2012). Other features of Instant Messaging make it easier to use, including a pop-up mechanism. Pop-ups have a function to display messages as they are received; visible "friend list" of contacts compiled by the user; and methods to indicate when 'friends' are online and available to receive messages (Alvestrand in Mesch, Talmud, \& Haase 2012). Another unique feature of the WhatsApp Instant Messaging application is the Status feature, which allows users to share their daily activities or activities. WhatsApp stories are popular among young people. In the 1827 age group, $46 \%$ reported using more frequently than email (Shiu \& Lenhart in Mesch, Talmud, \& Haase 2012). University students, part of the group mentioned above, use IM extensively. $28 \%$ reported more than 3 hours of use, $41 \%$ reported 12 hours of use, and 31\% reported using IM for less than one hour.

Several researchers have conducted similar research, including research conducted by Ling and Baron (2007), which examines the comparison of instant messaging via computer, and instant messaging via cell phone too. Another study by Carr, Schrock, and Dauterman (2012) examined speech acts on Facebook Messenger. Another research conducted by Mesch, Talmud, and Haase (2012) examines the characteristics, relationships, and culture generated by Instant Messaging. From previous research, no one has specifically reviewed certain features and functions of dualism Instant Messaging and 
shared features of daily activities such as what users can do on WhatsApp Instant Messaging. Therefore, researchers are interested in examining the Status feature on WhatsApp from the perspective of Media Ecology.

\section{Methods}

In this study, the authors conducted in-depth interviews with seven WhatsApp users who frequently use WhatsApp Status to share their daily activities. The technique of selecting informants using purposive. Purposive technique is a technique of data sources with specific considerations. Sugiyono (2016: 218) explains that specific considerations are, for example, the person who is considered to know what the researcher expects, so that it will make it easier for researchers to explore the object or social situation under study.

Several criteria or considerations used by researchers in selecting informants based on the following criteria: Informants are male or female aged 22-28 years. They use WhatsApp. They use WhatsApp status to share activities and information. They are willing to be interviewed by the author.

From these criteria, seven informants consisted of three women and four men. Four informants are student in university and three informants have worked. Following the agreement and agreement during the interview, the identity of the informant was not kept secret. The seven informants are:

Mukhsin (24 years), who is a student of S1 Communication Science, Surakarta State University. Mukhsin often uses WhatsApp status to share his daily activities and uses WhatsApp as the primary instant messaging to communicate with friends and family.

Ocha (22 years) currently has just earned a bachelor's degree in Communication Science from Gajah Mada University. Ocha uses WhatsApp and the Status feature to share important information because, according to Ocha, the contacts on WhatsApp are mostly office people where she is doing her internship.

Riza (27 years) is a Graphic Designer at a private company. Riza usually uses WhatsApp status to share information about Islam and quotes to motivate the people he contacts. However, Riza also admitted that Riza was often queued for privacy on WhatsApp status only for those closest.

Windi (21 years) is a student majoring in DKV at Telkom University Bandung. Windi uses WhatsApp stories to share about his daily activities.

Robert (23 years old) is a student majoring in Communication Science, Gajah Mada University. He uses WhatsApp status for any content. He calls it random contents.

Oktianasari (25 years old) is a Content Writer at a company engaged in the creative industry. She often uses WhatsApp to share information that she thinks is essential. She also controls who can see her status.

Sofyan (24 years) is a private employee. Sofyan often uses WhatsApp status to share important information such as holidays, disaster information, and share promotions related to his work.

\section{Results and Discussion}

The media ecology theory has three main assumptions. The first assumption underlines the idea that we cannot escape from the media in our life. Media encompasses our entire being. We cannot avoid or escape from the media. Many media ecology theorists interpret media in broad terms. McLuhan stated that the media is interpreted in a broad sense that is always present in our lives. These media transform society both through the games we play on the radio we listen to, the television we watch 
(West \& Turner 2008). Mukhsin, Ocha, and Robert admitted that WhatsApp Status cannot avoid not sharing daily activities and is always present in our lives. The following is an excerpt from the interview with Mukhsin:

"Ya biasanya aku bagi konten-konten yang bersifat kehidupan pribadi seperti saat bertemu teman, konten yang bersifat menghibur, edukasi, atau hal yang sedang menjadi trend."

("Yes, I usually share personal life contents such as meeting friends, entertaining, educational content, or things that are trending.")

"Karena menurut aku perlu untuk dibagikan kepada orang lain setiap hari gitu agar mereka juga mengetahui informasi terkini apa yang saya dapatkan."

("Because in my opinion, it is necessary to share it with other people every day so that they also know what the latest information I get.")

Mukhsin believes that he needs to share with others every day with entertaining and educational content and trending content. Ocha also expressed this, he even admitted that he used WhatsApp Status to build his image as a person who actively participates in volunteering. Here is an excerpt from an interview with Ocha:

"Basically, kalo aku pribadi aku udah bilang kalo WA itu kontak-kontaknya isinya keluarga kalo ga relasi yang profesional gitu, biasanya dari magang atau volunteer, kalo temen kuliah ada di platform lain sih. Jadi, aku berusaha buat apa yang aku tulis di status WhatsApp building personal image aja sih, jadi misalnya aku posting volunteering kan biar dikenal aku suka volunteering gitu sih."

("Basically, if I personally. I have said that WA's contacts are family or a professional relationship, or usually from internships or volunteers. About my college friends are on another platform. So, I try to write on WhatsApp status about building a personal image. For example, I post about volunteering to make people known that I like volunteering.")

While Robert prefers to post his personal life, "I like me to post," he admits that the posted content is sometimes not important at all or what he calls random contents. The following is an excerpt from the interview with Robert:

"Meaningless content (random office desks, surrounding scenery, holiday' greetings).. I just love seeing who is viewing my status hehe."

Windi, as a student, also likes various content regarding her daily life. The following is Windi's explanation during the interview:

"Biasanya tentang keseharian atau curhatan... untuk mengekspresikan dan mengceritakan kegiatan saya secara langsung dan cepat."

("Usually, about daily life or confession to express and tell my activities directly and quickly.")

In contrast to other informants such as Oktianasari, Sofyan, and Riza who chose to provide various information regarding important information or about opinions on a matter, for example, regarding views on religion as put forward by Riza: 


\begin{abstract}
“Untuk menshare personal opinion tentang sesuatu... tidak terlalu berbagai mengenai kehidupan pribadi soalnya biasanya yang aku share hadis-hadis jadi bisa bermanfaat secara personal dan publik."

("To share a personal opinion about something. Not too much various about personal life because usually what I share the hadiths is so it can be useful personally and publicly.")

“Lebih suka menshare mengenai promosi soal kerjaan sih, yang tidak terlalu personal.” (Wawancara dengan Sofyan).

("I prefer sharing work promotions, which are not too personal." (Interview with Sofyan))
\end{abstract}

\title{
Discussion
}

\section{WhatsApp and WhatsApp status feature as part of instant messaging}

Instant Messaging (IM) is one of many people's many communication services. The advent of Instant Messaging in recent years has become a huge phenomenon. Instant Messaging allows a person to communicate with other people in real-time via the internet or intranet. Because Instant Messaging only requires less bandwidth, so it requires lower costs than using a telephone. Based on this convenience, businesses began to see Instant Messaging as an alternative means of communication. Currently, several Instant Messaging applications are quite popular among internet users, including Yahoo! Messanger, ICQ, MSN Messenger, and AIM (Sukarno 2011; N.N. no date).

According to the Digital Library Telkom Institute of Technology (http://digilib.ittelkom.ac.id), states that Instant Messaging is an application that utilizes Internet technology. Users can use the application to send instant messages at the same time (real-time) using text to other users who are connected to the same network Meisyaroh (2014). Meanwhile, according to Mohammad Gilang Kautzar Hw in Meisyaroh (2014), an instant messenger is a software that facilitates sending short messages (Instant Messaging), a form of direct communication between two or more parties using typed text (chat). Instant message sender will send text via network-connected devices. This technology has an advantage over electronic mail (e-mail); namely, communication can be established directly or in real-time. That is one of the reasons for the rapid growth in the use of instant messengers to communicate.

Currently, there are various kinds of Instant Messaging, according to Eztalks (2017), such as WhatsApp, Skype, Viber, Meebo, Kik, We Chat, Messenger. Eztalks (2017) further explains that the most well-known IM is WhatsApp. WhatsApp is a well-known instant messaging application that many users use to chat with friends and colleagues. One of the reasons for the popularity of this application is the simplicity of use. It is also reliable, and the public does not have to follow lengthy registration procedures. The public only needs an internet connection on the mobile device (handphone), and then users can connect on WhatsApp and send text messages, files, videos, and pictures. Users can also enjoy video and voice calls, and share their daily activities through WhatsApp Story.

WhatsApp is the premier mobile instant messaging application that allows users to send and receive real-time and diverse information to individuals and groups (Aharony \& Zion 2018). WhatsApp is in the top 20 apps on the App Store worldwide. In 2013, the WhatsApp user base was enlarged to 200 million active users. WhatsApp has more than 450 million active users, and is reaching that number faster than any other company in history, said Jim Goetz, of Sequoia Capital, who has invested in the company. Competing with several Asian-based messaging services such as LINE, KakaoTalk, WeChat, WhatsApp handled ten billion messages per day in August 2012, growing from two billion in April 2012, and one billion in the previous October. On 13 June 2013, WhatsApp announced that they had reached their new diary by processing 27 billion messages. As of 10 November 2013, WhatsApp has more than 190 million monthly active users, 400 million photos are shared every day, and the messaging system handles more than 10 billion messages every day (https://visual.ly). 
In 2018, WhatsApp had an additional feature, namely, WhatsApp Status. WhatsApp Status is next to chats and calls. In that panel, the user can see all the status by the user's most recent contact. WhatsApp Status remains active for 24 hours from the time of upload. People can upload multiple statuses in one day. To view the next or previous contact status, tap the right or left edge of the screen, respectively. Users can move to the next contact status, by swiping left. Users can also provide comments for each current status. Users can comment on a status, by swiping up. WhatsApp status is like Snapchat or Instagram Stories, users can see who has seen status, and anyone can also reply to a status. Users also have many options to limit who can see WhatsApp's status (Patkar 2018). The following figure 1 shows the number of WhatsApp users in 2013.

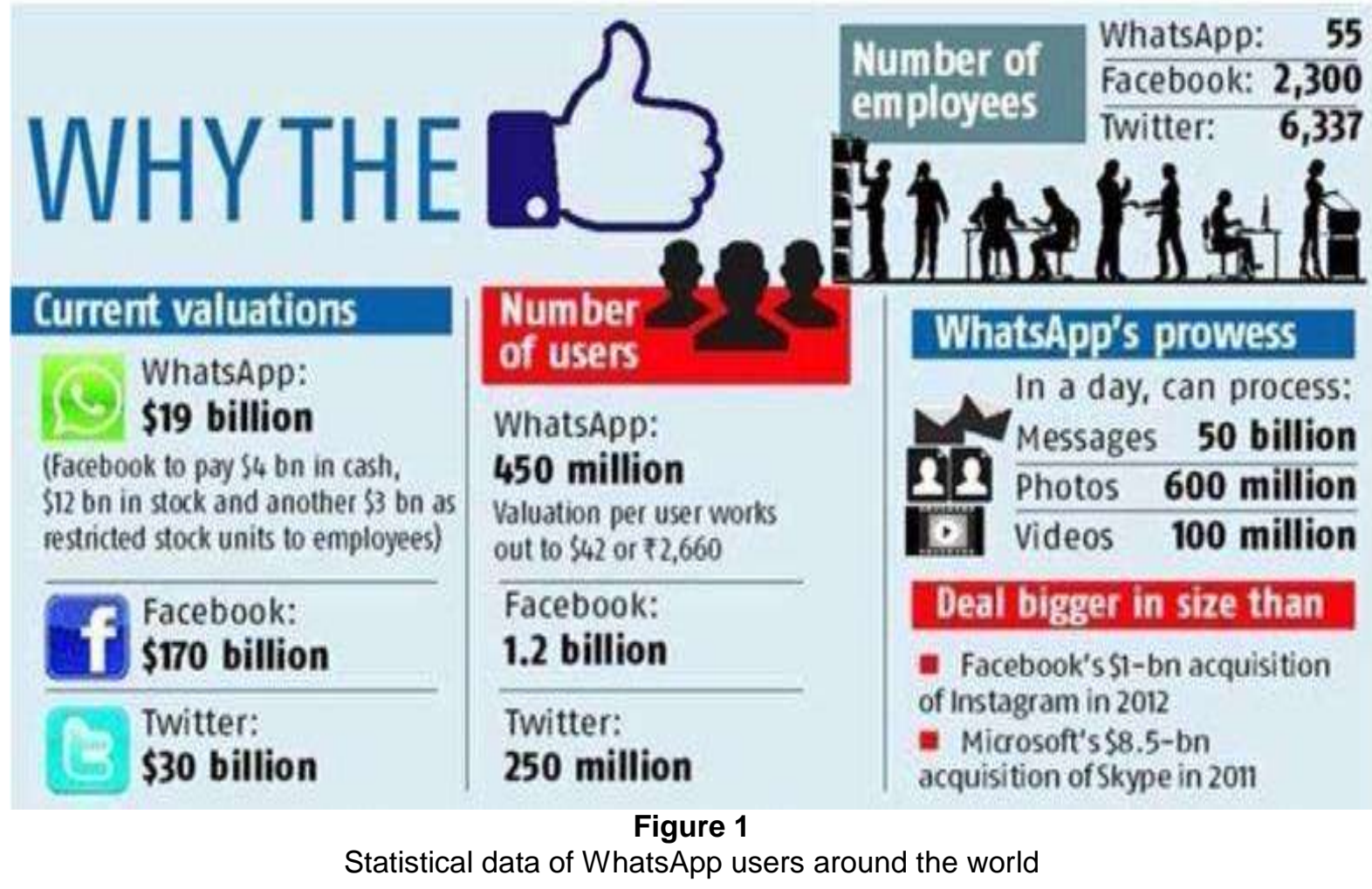

WhatsApp Messenger is a cross-platform instant messaging application for smartphones. Apart from text messaging, users can send pictures, videos, contacts, audio messages, and location. Recently also launched Push to talk and WhatsApp Status services for its users. Another advantage it provides over conventional text messages is that users can use WhatsApp Story to share videos or photos about anything, including their daily activities. That is where WhatsApp comes in to make life more comfortable for Smartphone users. It is available for Android, BlackBerry OS, BlackBerry 10, iOS, Nokia Series 40, Symbian (S60), and Windows Phone. Its main USP is to provide unlimited messages between WhatsApp users for free. The convenience of adding friends to one's profile and the ease of use makes it easy to use and popular with users. Another factor that attracts users is the arrangement of emoticons it provides. That allows users to express their feelings better and convey their thoughts (https://visual.ly). 


\section{User Bases For Apps With 'Stories' \\ Daily/Monthly Users (In Millions)}

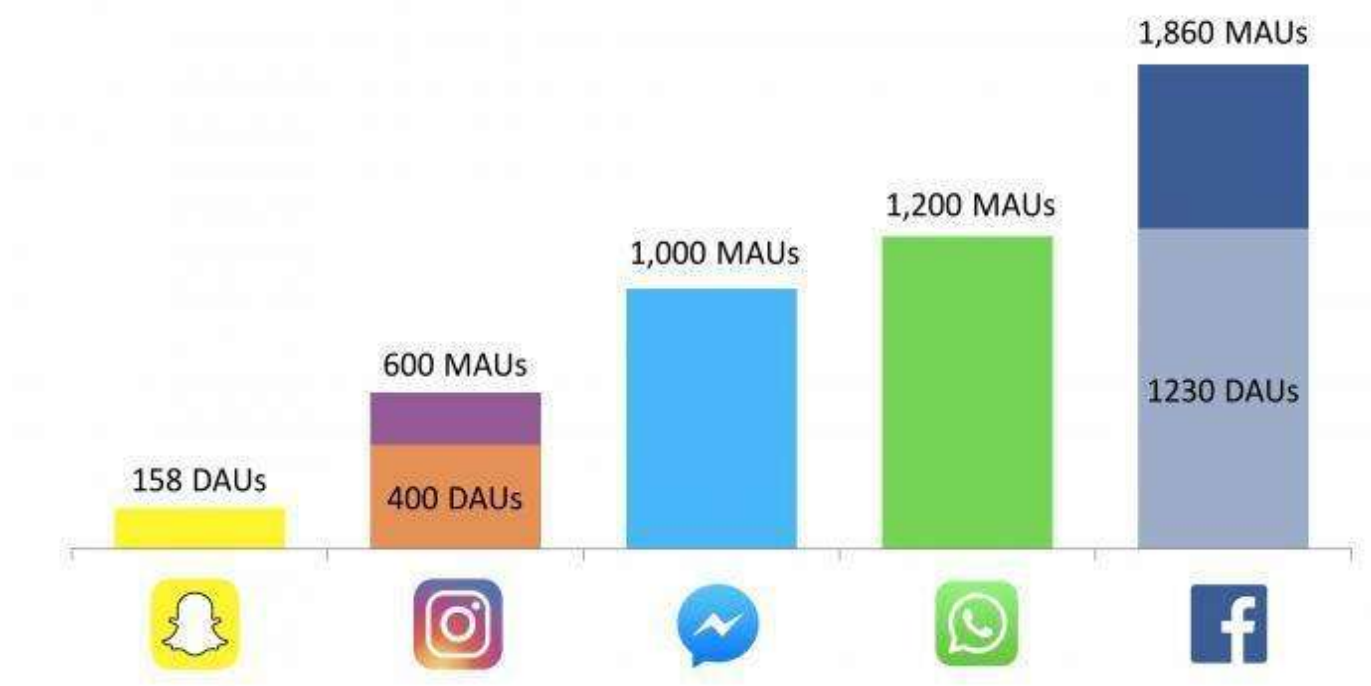

Note: Messenger and WhatsApp do not disclose daily active users. Source: Snap S-1, Facebookearnings, Componyupdates, 2016-2017

\section{Figure 2}

BI INTELLiGENCE

Story feature user statistics data on instant messaging

(Elder 2017)

According to Elder (2017), in Business Insider (https://www.businessinsider.com), WhatsApp usage metrics indicate that the new status feature will hit. According to statistics cited by Bloomberg, there are already 3.3 billion photos sent via the platform every day, double the number last year, and users send 760 million videos and 80 million GIFs daily. With this in mind, WhatsApp wanted to update the product to suit user behavior.

New features can also open up new monetization opportunities. Facebook plans to monetize WhatsApp remain unknown, but the company could easily follow the templates set by Snapchat and Instagram and run full-screen ads between WhatsApp statuses. In 2017, WhatsApp recruited Matthew Idema, a senior Facebook executive in marketing and advertising, as its first COO - a strong indication that messaging apps are getting serious about earning money.

From the explanation above, it shows that the Stories feature in Instant Messaging, WhatApp leads with a figure of 1200 when compared to Instagram and Facebook, which both have story features. That proves that WhatsApp Instant Messaging is not only used for communication, but also users can use it to share their daily activities from photos to videos and become part of their daily needs.

\section{Status features on WhatsApp instant messaging in media and communication ecology perspective}

The rapid changes and extraordinary developments in information and telecommunications technology have affected all areas of life. Every individual now does not need to meet or meet face to face to communicate. Modern technology has supported the invention of many functional and utility devices such as smart-watches and smartphones. With all these revolutions, technology is also making our lives easier, faster, better, and more enjoyable. In terms of how we communicate, modern technology has had a significant impact. Digital technology has also changed what people refer to as 'media.' Media companies are no longer a news platform. Media companies are no longer a news 
platform, as people now recognize them as companies that help convey information worldwide. The global active web user is now close to 3.2 billion people. That is almost half of the world's population. Worldwide, two million smartphones are sold every day. The amount of information carried on social media networks is phenomenal. Social media is not the only big digital tech statement. Nor is social media, the only way technology impacts everyone's life.

The existence of Instant Messaging has changed the way every Instant Messaging user has changed the way he communicates. Instant Messaging or instant messaging is an application that utilizes Internet technology where users can use the application to send short messages directly at the same time (real-time) using text to other users who have connected to the same network. Meanwhile, according to Mohammad Gilang Kautzar Hw (in Meisyaroh 2014), electronic media has radically changed society, according to McLuhan. In essence, McLuhan feels that society is highly dependent on technology that uses media and that society's social order is based on its ability to deal with technology to shape and organize a culture (West \& Turner 2008). This ecological theory focuses on many types of media. It views the media as an environment, which states that Lance Strate's definition of media ecology is studying and communication codes playing a significant role in human life (Meisyaroh 2014).

Based on the seven informants' opinions, it shows that informants can't separate from WhatsApp in everyday life. It is also following McLuhan's expression that technology cannot be separated from aspects of life (Levinson 2000). It can be seen that there is a relationship between the presence of features in instant messaging and the media ecology because media ecology talks about environmental studies of media. That is the same as other existences such as WhatsApp Status with WhatsApp Instant Messaging so that its function is not only as communication but also as a medium for various daily activities.

A famous statement from media ecology theory is that the medium is the message, or the medium is the message. The statement represents the power and influence of the medium on society, not the content but the medium used. The medium can change how we think about other people, ourselves, and the world around us. Although the medium is the core of this theory, McLuhan in Levinson (2000) also states that content or content also gets more attention from us than the medium. However, what influences perception the most is that the medium is not the content. The Story / Status feature in instant messaging is a medium that can send and share photos and videos about daily activities as a form of self-existence so that WhatsApp as Instant Messaging is not only a tool for sending messages but also for sharing daily activities.

The emergence of various features in the Instant Messaging application is the impact of the power of technology and the medium's influence in sending and receiving messages instantly. Even in our daily activities, it is never separated from Instant Messaging and the desire to share daily activities with followers or the closest people. In instant messaging contacts. The seven informants also expressed that using WhatsApp status can also build a personal image (personal image building). As expressed by the informant Mukhsin who wanted to be known as a humorous, smart, and active person:

"Pengen dikenal orang sebagai orang yg humoris, smart, energic, up to date, fashionable."

("I want to be known as someone who is humorous, smart, energetic, up to date, and fashionable.").

While Ocha wants to be known as a person who is active in volunteering, Robert wants to be known as a person who is not too serious.

"Aku pengen bangun personal image, aku memfilter konten-konten yang aku ingin perlihatkan untuk relasi-relasi ku secara profesional, ga yang setiap saat update di status WA." 


\section{Apriliyanti: Ecological media perspective on WhatsApp status features}

("I want to build a personal image, I filter the content that I want to show for my relationships professionally, not which updates on WA status every time.")

Meanwhile, Oktianasari wanted to present an independent and informative person, as well as Sofyan, who wanted to be known as a hard worker and independent. The following are excerpts from interviews with Oktianasari and Sofyan:

"Pengen terlihat jadi pribadi yang mandiri dan informatif gitu..." (Wawancara dengan Oktianasari) ("I want to be seen as an independent and informative person." (Interview with Oktianasari)).

"Ya pencitraan biar kesannya kerja terus gitu lah." (Wawancara dengan Sofyan)

("Yes, imaging, so that the impression is that I always work." (Interview with Sofyan)).

The use of WhatsApp status requires high participation. Users can set privacy so that a few people can only see the content. These informants revealed that by regulating privacy for some people, it would prevent misunderstandings or perceptions from certain parties. As stated by Riza, he admitted that he often hid the WhatsApp content of his superior status because it would create perceptions or opinions about Riza from his superior's view. The following is Riza's explanation during the interview:

"Setiap saat mau posting selalu ku cek sih bagian privacy dan selalu mengatur siapa yang berhak ngeliat atau aku males aja kalo misalnya diliat sama orang tertentu, kayak atasan. Ntar aku dijudge gimana kan."

("Every time I want to post, I always check the privacy section and always set who can be seen or, I'm just lazy to see certain people, such as my superiors. How will I be judged later??").

Meanwhile, Ocha often regulates his privacy to people he thinks are disturbing and often replies to their WhatsApp status. The following is an excerpt from Ocha's interview during the interview:

"Sampai sekarang Cuma sedikit Cuma sedikit kali ya yang bisa melihat wa story aku, karena aku tahu dia ini suka ngereply status aku dan aku orangnya itu yang ga aku suka. Jadi aku hide dari orangorang yang aku ga suka kalo aku direply."

("Until now, only a few people have been able to see my story's WA because I know that he likes replying to my status, and he is the person I don't like. So I hide it from people that I don't like when I got replying.")

While Mukhsin often adjusts privacy on WhatsApp status because he feels that other people might be uncomfortable or feel bored with the content he uploaded. The following is an excerpt from the interview with Mukhsin:

"Selalu, bahkan sering ketika akan membuat status kemudian saya batalkan karena menurut saya akan menganggu kenyamana orang lain."

("Always, often, when I make a status, I cancel it because I think it will disturb other people's comfort.") 
"Pernah. Biasanya ketika itu menyangkut kehidupan pribadi saya, misalnya ketika saya masak di dapur atau sedang berbuka puasa hahah, meskipun konten tersebut menarik, tapi tidak semua orang lain melihat konten tersebut. Atau bisa juga ketika saya sudah membuat story satu hingga dua kali dalam sehari, maka saya urungkan niat saya agar orang lain tidak merasa jenuh."

("Ever. Usually, when it comes to my personal life. For example, when I cooked in the kitchen or breaking the fast, hahaha. Even though the content is interesting, but not everyone sees the content, or when I've made a story, one or two times a day, so I undo my intention so that other people don't feel bored.")

This explanation found that WhatsApp media was included in cold media that required high participation. In media ecology theory, hot and cold media are distinguished. The Status feature on WhatsApp Instant messaging is a cool medium. Cold media are media that require high levels of participation and are low in the definition. The medium provides little and much the audience has to complete themselves. Cold media requires audiences to create meaning through high and imaginative sensory involvement (West \& Turner 2008). That is because the WhatsApp Status Instant Messaging feature requires high and low definition participation. After all, it requires the audience to create meaning through high and imaginative sensory involvement through messages sent and received so that communication misunderstandings do not occur.

\section{Conclusion}

There are several conclusions that researchers can take from this study. The emergence of various features in the Instant Messaging application is the impact of the power of technology and the medium's influence in sending and receiving messages instantly. Even in our daily activities, it is never separated from Instant Messaging. The Story feature in instant messaging is a medium that can send and share photos and videos. Based on seven informants, the WhatsApp status feature usually contains daily activities as a form of self-existence. WhatsApp as Instant Messaging is a tool for sending messages and sharing daily activities. Besides, some informants use this feature to share their knowledge or ideas with others.

The Status feature on WhatsApp Instant messaging is a cool medium. Cold media are media that require high levels of participation and are low in the definition. The WhatsApp Status feature in Instant Messaging requires high and low definition participation. It requires the audience to create meaning through high and imaginative sensory involvement through messages sent and received so that communication misunderstandings do not occur.

\section{References}

Aharony N \& Zion A (2016) Effect of WhatsApp use on working performance among youth. Journal of Education Computing Research 57 (1): 226-245.

Barker C (2015) Cultural studies: Teori dan praktek. Yogyakarta: Kreasi Wacana.

Carr TC, Shrock DB, \& Dauterman P (2012) Speech acts within Facebook Status Message. Journal of Language and Social Psychology 31 (2): 176-196.

Elder R (2017) WhatsApp now has its own stories. [Diakses 7 April 2019]. https://www.businessinsider.com/WhatsApp-now-has-its-own-stories-clone-2017-2/?IR=T

Eztalks (2017) 8 Examples of instant messaging. [Diakses 7 April 2019]. https://www.eztalks.com/unified-communications/examples-of-instant-messaging.html

Hildrebrand JM (2018) Modal Media: connecting media ecology and mobilities research. Media, Culture and Society 40 (3): 348-364.

Kementerian Komunikasi dan Informatika (2017) [Diakses 7 April 2019]. https://kominfo.go.id/. 
Levinson P (2000) McLuhan and Media Ecology. In: Proceedings of the media ecology association, 16-17 Juni 2000. Media Ecology Association, 17-22.

Ling R \& Baron NS (2007). Text message and IM: Linguistic of American College. Journal of Languange and Social Psychology 26 (3): 291-298

McLuhan M (1964) Understanding Media: the extension of man. [Diakses 8 April 2019]. http://web.mit.edu/allanmc/www/mcluhan.mediummessage.pdf.

Meisyaroh S (2014) Instant messaging dalam perspektif ekologi media dan komunikasi. Media dan Perilaku Masyarakat Kontemporer 1 (1): 118-130.

Mesch GS, Talmud I, \& Haase AQ (2012) Instant messaging social networks: individual, relational, and cultural characteristic. Journal of Social and Personal Relationship 29 (6): 736-759.

Mukhsin (2019) [Personal communication] 17 June.

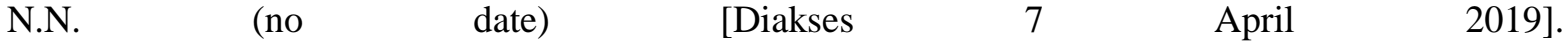
http://sinta.ukdw.ac.id/sinta/resources/sintasrv/getintro/22084515/c5584619cdf2c47a9c60717928 871a64/intro.pdf.

Ocha (2019) [Personal communication] 16 June.

Oktianasari (2019) [Personal communication] 18 June.

Patkar M (2018) The best new WhatsApp features you might have missed. [Diakses 7 April 2019]. https://www.makeuseof.com/tag/6-new-WhatsApp-features-you-should-know-about/.

Riza (2019) [Personal communication] 17 June.

Robert (2019) [Personal communication] 18 June.

Sofyan (2019) [Personal communication] 20 June.

Sugiyono (2016) Metode penelitian kuantitatif, kualitatif, dan R\&D. Bandung: Alfabeta.

Sukarno AS (2011) Rancangan Bangun Aplikasi Secure Instant Messaging Memanfaatkan Protokol Instant Messaging Key Exchange dengan Penambahan Konsep Digital Signature dan Penggunaan Dongle sebagai Pengaman Aplikasi. In: Konferensi Nasional Sistem dan Informatika, 12 November 2011, Bali. Bali, STMIK STIKOM, 102-107.

Tjokro LK (2016) Peran Media Sosial dalam Membentuk dan Menggerakan Gerakan Sosial: Studi Kasus pada Akun@ketimbang.ngemis.soloo di Instagram dalam Membentuk dan Menggerakan Gerakan Sosial Anti Mengemis di Solo. Skripsi, Universitas Kristen Satya Wacana, Salatiga.

West R \& Turner LH (2008) Pengantar teori komunikasi: analisis dan aplikasi (edisi 3). Jakarta: Salemba Humanika.

Whatsapp Success Story (no date) [Diakses 7 April 2019]. https://visual.ly/community/Infographics/technology/whatsapp-success-story.

Windi (2019) [Personal communication]. 